\title{
Corrigendum: Monitoring Cerebral Oxygenation in Neonates: An Update
}

\author{
Laura Marie Louise Dix ${ }^{1,2}$, Frank van Bel ${ }^{1}$ and Petra Maria Anna Lemmers ${ }^{1 *}$ \\ 'Department of Neonatology, Wilhelmina Children's Hospital, University Medical Center, Utrecht, Netherlands, \\ ${ }^{2}$ Monash Newborn, Monash Medical Centre, Melbourne, VIC, Australia
}

Keywords: near-infrared spectroscopy, cerebral oxygenation, neonates, neonatal intensive care, neonatal neurology

\section{A Corrigendum on}

Monitoring Cerebral Oxygenation in Neonates: An Update

by Dix LML, van Bel F, Lemmers PMA. Front Pediatr (2017) 5:46. doi: 10.3389/fped.2017.00046

Cerebral Oxygenation and the Patent Ductus Arteriosus

The hemodynamically significant patent ductus arteriosus (PDA) remains a controversial topic. Clinicians and researchers are still debating whether or not it should be treated, what the best treatment strategy is and when would be the best time to intervene (48-51).

Reference 48-51 are:

Edited by:

Utpal S. Bhalala,

Baylor College of Medicine,

United States

Reviewed by:

Narendra Reddy Dereddy, Maria Fareri Children's Hospital,

United States

*Correspondence:

Petra Maria Anna Lemmers

p.lemmers@umcutrecht.nl

Specialty section:

This article was submitted to Pediatric Critical Care,

a section of the journal

Frontiers in Pediatrics

Received: 29 May 2017

Accepted: 06 July 2017

Published: 21 July 2017

Citation:

Dix $L M L$, van Bel F and Lemmers PMA (2017) Corrigendum: Monitoring Cerebral Oxygenation

in Neonates: An Update.

Front. Pediatr. 5:160.

doi: 10.3389/fped.2017.00160
48. Tsuji M, Saul JP, du Plessis A, Eichenwald E, Sobh J, Crocker R, et al. Cerebral intravascular oxygenation correlates with mean arterial pressure in critically ill premature infants. Pediatrics (2000) 106(4):625-32. doi:10.1542/peds.106.4.625

49. Brady KM, Mytar JO, Lee JK, Cameron DE, Vricella LA, Thompson WR, et al. Monitoring cerebral blood flow pressure autoregulation in pediatric patients during cardiac surgery. Stroke (2010) 41(9):1957-62. doi:10.1161/STROKEAHA.109.575167 PMID:20651273

50. Wong FY, Leung TS, Austin T, Wilkinson M, Meek JH, Wyatt JS, et al. Impaired autoregulation in preterm infants identified by using spatially resolved spectroscopy. Pediatrics (2008) 121(3):e604-11. doi:10.1542/peds.2007-1487 PMID:18250118

51. Caicedo A, Alderliesten T, Naulaers G, Lemmers P, van Bel F, Van Huffel S. A new framework for the assessment of cerebral hemodynamics regulation in neonates using NIRS. Adv Exp Med Biol (2016) 876:501-9. doi:10.1007/978-1-4939-3023-4_63 PMID:26782251

However, these references are supposed to be:

- Perez KM, Laughon MM. What is new for patent ductus arteriosus management in premature infants in 2015? Curr Opin Pediatr (2015) 27(2):158-64. doi:10.1097/MOP.0000000000000200

- Evans N. Preterm patent ductus arteriosus: a continuing conundrum for the neonatologist? Semin Fetal Neonatal Med (2015) 20(4):272-7. doi:10.1016/j.siny.2015.03.004 PMID:25818393

- Ibrahim TK, Haium AA, Chandran S, Rajadurai VS. Current controversies in the management of patent ductus arteriosus in preterm infants. Indian Pediatr (2014) 51(4):289-94. doi:10.1007/ s13312-014-0403-2 PMID:24825266

The authors apologize for this error and state that this does not change the scientific conclusions of the article in any way. 
Conflict of Interest Statement: The authors declare that the research was conducted in the absence of any commercial or financial relationships that could be construed as a potential conflict of interest.

Copyright (C) 2017 Dix, van Bel and Lemmers. This is an open-access article distributed under the terms of the Creative Commons Attribution License (CC BY).
The use, distribution or reproduction in other forums is permitted, provided the original author(s) or licensor are credited and that the original publication in this journal is cited, in accordance with accepted academic practice. No use, distribution or reproduction is permitted which does not comply with these terms. 